\title{
The impact of Red Cell Distribution Width and Neutrophil/Lymphocyte Ratio on Long-term Survival after Pulmonary Resection for Non-Small Cell Lung Cancer
}

\author{
Serkan UYSAL ${ }^{1}$, Tuba SAHINOGLU ${ }^{2}$, Ulas KUMBASAR ${ }^{3}$, Metin DEMIRCIN ${ }^{4}$, \\ Ilhan PASAOGLU ${ }^{4}$, Riza DOGAN ${ }^{4}$ \\ ${ }^{1}$ Bolu Izzet Baysal State Hospital, Department of Thoracic Surgery, Bolu \\ ${ }^{2}$ Sivas Numune Hospital, Department of Thoracic Surgery, Sivas \\ ${ }^{3}$ Hacettepe University Faculty of Medicine, Department of Cardiovascular Surgery, Ankara \\ ${ }^{4}$ Hacettepe University Faculty of Medicine, Department of Thoracic Surgery, Ankara, TURKEY
}

\begin{abstract}
Red cell distribution width (RDW) and Neutrophil/Lymphocyte Ratio (NLR) are widely available blood tests which can be used to reflect patients' inflammatory status. We investigated the effects of RDW and NLR levels on long-term survival after pulmonary resection for non-small cell lung cancers. Data were compiled retrospectively from 249 patients. We found a significant correlation between higher RDW and NLR levels and poorer prognosis. Overall survival rates of patients with high and normal RDW levels were $42 \pm 7$ and $84 \pm 12$ months, respectively $(p=0.019)$. In addition, disease free survival rates of patients with high and normal RDW levels were $62 \pm 6$ and $76 \pm 4$ months ( $p=0.047$ ), respectively. When NLR levels were divided into tertiles we observed significantly poorer overall and disease free survival in ascending tertiles. The overall and disease free survival rates in the lower through upper tertiles were; $88 \pm 6,80 \pm 6$, $50 \pm 5$ months for overall and $87 \pm 6,77 \pm 6,47 \pm 5$ months for disease free survival $(p<0.001)$. In conclusion, the ability to accurately predict sub-sets with poorer outcomes among patients who had undergone pulmonary resection for non-small cell lung cancers is important. RDW and NLR are biomarkers which could influence patients categorization in this regard. Preoperative measurement of these potential markers are simple, adds no additional cost to routine preoperative workup and can be used to identify patients with poorer prognosis.
\end{abstract}

Keywords: Red cell distribution width, Neutrophil/Lymphocyte Ratio, survival, pulmonary resection, non- small cell lung cancer

ÖZET

Eritrosit Dağılım Genişliği (RDW) ve Nötrofil/Lenfosit Oranının (NLR) Rezeksiyon Uygulanan Küçük Hücreli Dışı Akciğer Kanserli Hastalarda Uzun Dönem Sağkalıma Etkisi

Eritrosit dağılım genişliği (RDW) ve nötrofil/lenfosit oranı (NLR) yaygın olarak kullanılan ve hastaların inflamatuar durumunu gösteren kan testleridir. Çalışmamızda akciğer rezeksiyonu uygulanan küçük hücreli dışı akciğer kanserli hastalarda bu belirteçlerin uzun dönem sağkalıma etkisini araştırmayı amaçladık. İkiyüz kırkdokuz hastanın verileri retrospektif olarak incelendi. Yüksek RDW ve NLR seviyeleri ile kötü prognoz arasında ciddi bir korelasyon olduğu saptandı. Genel sağkalım yüksek ve normal RDW seviyelerinde sırasıyla $42 \pm 7$ ile $84 \pm 12$ ay ( $p=0.019)$ iken hastalıksız sağkalım 62 \pm 6 ile 76 \pm 4 ay ( $p=0.047)$ olarak hesaplandı. NLR seviyeleri üç ana gruba ayrıldığında, NLR seviyesi yükseldikçe prognozun kötüleştiği gözlemlendi. En alt seviye grubundan üst seviye grubuna gidildikçe genel sağkalım sırasıyla $88 \pm 6,80 \pm 6$ ve $50 \pm 5$ ay ( $p<0.001)$, hastalıksı sağkalım ise $87 \pm 6,77 \pm 6$ ve $47 \pm 5$ ay $(p<0.001)$ olarak bulundu. 
International Journal of Hematology and Oncology

Sonuç olarak akciğer rezeksiyonu uygulanan küçük hücreli dışı akciğer kanserli hastalarda kötü prognoza sahip alt-grup hastalarını saptamak önemlidir. Preoperatif ölçülmleri oldukça basit ve masrafsız olan RDW ve NLR değerleri preoperatif rutin değerlendirmeye katılarak bu amaçla kullanılabilecek parametreler olabilirler.

Anahtar Kelimeler: Eritrosit dağlım genişliği, Nötrofil/lenfosit oranı, Sağkalım, Pulmoner rezeksiyon, Küçük hücreli dışı akciğer kanseri

\section{INTRODUCTION}

Red cell distribution width (RDW) is routinely examined with complete blood count (CBC) test and is a measure of variability in the size of circulating erythrocytes. Clinically, it is used for differentiating different types of anaemia and may also be found elevated in chronic inflammation, uraemia and poor nutritional status. ${ }^{1,2}$ Recent studies have demonstrated that elevated RDW levels are associated with poor prognosis in patients with cardiovascular disease, stroke, septicemia, chronic obstructive pulmonary disease and older age..$^{3-5}$ However, few studies have investigated RDW levels in lung cancer patients. ${ }^{6,7}$

Neutrophil/Lymphocyte Ratio (NLR), an inexpensive and widely available blood test, can also be used for evaluating cell-mediated immune responses and reflects patients' inflammation status. ${ }^{8}$ It has been found to be an important indicator of prognosis in various cancer types including colorectal, gastric, metastatic melanoma, renal cell carcinoma and pancreatic cancer. ${ }^{9-12}$ Recently, increasing preoperative neutrophil/lymphocyte ratios were found to be an independent predictor of survival after complete resection for primary lung cancer. ${ }^{13}$

In this study, we aimed to investigate the effects of preoperative levels of RDW and NLR on longterm survival in patients who had undergone pulmonary resection for non-small cell lung cancer.

\section{PATIENTS and METHODS}

Two hundred and ninety-three patients who underwent complete resection for non-small cell lung cancer between January 2002 and December 2012 were retrospectively studied. Exclusion criteria included any patients with coexistent hematologic disorders or known active infection at the time of surgical intervention. This study has been approved by the Ethical Committee of Hacettepe University Faculty of Medicine and written consent has been waived.
Data were compiled from individual patient notes, electronic patient records and pathology reports. Samples were collected from patients using routine methods at the time of diagnosis. NLR was defined as the absolute neutrophil count divided by the absolute lymphocyte count. NLR was analysed as a continuous variable and by tertiles to aid graphical representation of the results. NLR tertiles were defined as 1st NLR: 0.3-2.1, 2nd NLR: 2.1-3.5 and 3rd NLR: 3.5-29.6. Normal range in our laboratory for RDW was $11.7 \%$ to $14.6 \%$, patients were divided into high RDW (RDW $\geq 14.6 \%$, $\mathrm{n}=92$ ) group and normal RDW (RDW: 11.7\%-14.6\%, n= 157) group. Survival status was determined from the date of last follow-up. Mortality status was documented from patient records and the National Health Service database.

\section{Statistical Analysis}

Statistical analyses were carried out with IBM SPSS for Windows version 21.0 statistical software (IBM Co., Armonk, NY, USA). Continuous variables were presented as mean \pm standard deviation and categorical variables as frequencies and percentages. Categorical variables were compared using "chi-square test". Normality was assessed by Shapiro-Wilks test. Differences in continuous values between two groups were assessed with MannWhitney $\mathrm{U}$ tests for non-normally distributed variables. Actuarial survival was estimated by using the Kaplan-Meier method, and differences were tested with the log-rank test. NLR values were expressed in tertiles to retain sufficient numbers per group for comparison. A p value $<0.05$ was considered statistically significant.

\section{RESULTS}

Totally, 249 patients consisting of 208 males and 41 females, ranging from 35 to $81(60.8 \pm 9.1)$ years with 188 having a smoking history were enrolled in this study. The characteristics of the study popu- 
Table 1. Pre, peri and postoperative characteristics of patients $(n=249)$

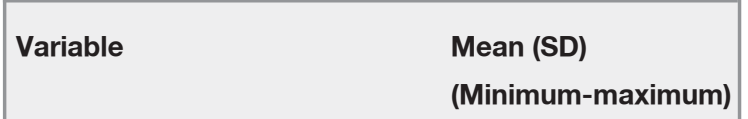

Preoperative

Age (years)

Male (\%)

$60.8(9.1)(35-81)$

Diabetes (\%)

208 (83.5)

Hypertension (\%)

$22(8.8)$

Coronary artery disease (\%)

$54(21.7)$

38 (15.3)

COPD (\%)

$18(7.2)$

Smoking history

$188(47.3)$

FEV1 (I)

Hemoglobin

RDW

NLR

Operative

Pneumonectomy (\%)

Lobectomy (\%)

Segmentectomy-wedge resection (\%)

Histology (\%)

Squamous carcinoma

$114(45.8)$

Adenocarcinoma

$93(37.3)$

Large-cell carcinoma

21 (8.4)

$21(8.4)$

Postoperative

Pathologic stage (\%)

IA

$89(35.7)$

IB

$50(20.1)$

IIA

51 (20.5)

IIB

$23(9.2)$

IIIA

36 (14.5)

Air leak > 7 days (\%)

Postoperative ventilator support (\%)

Reoperation (\%)

49 (19.7)

$17(6.8)$

4 (1.6)

Atelectasis (\%)

$32(12.9)$

Rhythm disturbances (\%)

$21(8.4)$

Surgical site infection (\%)

$3(1.2)$

Hospital stay (days)

$9.9(7.9)(4-60)$

COPD: Chronic obstructive pulmonary disease; RDW: Red cell distribution width; NLR: Neutrophil/Lymphocyte ratio lation are given in Table 1. The median follow-up time for the cohort was 26 months. The overall 1-, 3 - and 5-year survival rates were $85 \%, 66 \%$ and $50 \%$, respectively.

The median overall and disease free survival rates of patients associated with RDW and NLR levels are presented in Table 2. Kaplan-Meier analysis showed that patients with high RDW levels had significantly lower overall and disease free survival rates than patients with normal RDW levels $(\mathrm{p}=$ 0.019 and $p=0.047$, respectively) (Figure $1 \mathrm{~A}-\mathrm{B}$ ). Similarly, High NLR levels were observed to be associated with lower overall and disease free survival rates ( $\mathrm{p}<0.001$ for both) (Figure 2 A-B).

\section{DISCUSSION}

RDW, which quantifies the variability in the volume of red blood cells, is routinely examined with the CBC test. Elevation of RDW levels are considered to be associated with chronic inflammation, poor nutritional status and age-associated diseases via changes in erythropoiesis. ${ }^{1,2,14}$

Chronic inflammatory response is clearly implicated in the functional decline of the cancer patient and their subsequent poor outcome. ${ }^{15}$ The exact mechanisms of inflammation on RDW levels are unknown, but potential mechanisms include impairing iron metabolism, inhibiting the response to erythropoietin, and decreasing red blood cell survival via production of inflammatory markers. ${ }^{15,16}$

To date, few studies investigate the association of RDW with respect to mortality and long-term survival in patients with lung cancer., ${ }^{714}$ Recently, Warwick et al. evaluated patients undergoing pulmonary resections for non-small-cell lung cancer and concluded that RDW is a significant factor after risk adjustment, determining in-hospital morbidity, mortality and long-term survival. ${ }^{7}$ Our study confirmed their results and found that patients who had undergone pulmonary resections for non-small cell lung cancer with high preoperative RDW levels had significantly lower overall and disease free survival rates than patients with normal RDW levels. As shown in Table 2, Overall survival rates of patients with high and normal RDW levels were $42 \pm 7$ and $84 \pm 12$ months, respectively $(p=0.019)$. Similarly, disease free survival rates of patients 


\begin{tabular}{|c|c|c|c|c|c|c|}
\hline & $\mathbf{n}$ & $\%$ & $\begin{array}{l}\text { Overall survival } \\
\text { (95\% Cl) (months) }\end{array}$ & p-value & $\begin{array}{l}\text { Disease free survival } \\
\text { (95\% Cl) (months) }\end{array}$ & $\mathrm{p}$-value \\
\hline \multicolumn{7}{|l|}{ RDW } \\
\hline High RDW & 92 & 36.9 & $42 \pm 7$ & 0.019 & $62 \pm 6$ & 0.047 \\
\hline Normal RDW & 157 & 63.1 & $84 \pm 12$ & & $76 \pm 4$ & \\
\hline \multicolumn{7}{|l|}{ NLR } \\
\hline 1st tertile & 83 & 33.3 & $88 \pm 6$ & $<0.001$ & $86 \pm 6$ & $<0.001$ \\
\hline 2nd tertile & 83 & 33.3 & $80 \pm 6$ & & $77 \pm 6$ & \\
\hline 3rd tertile & 83 & 33.3 & $50 \pm 5$ & & $47 \pm 5$ & \\
\hline
\end{tabular}

with high and normal RDW levels were $62 \pm 6$ and $76 \pm 4$ months ( $\mathrm{p}=0.047$ ), respectively.

NLR, as a measure of the relative differences of the baseline neutrophil and lymphocyte counts also reflects patients' immune status and similarly found to be associated with poor outcome in various cancer patients. Neutrophils are accepted as a major source of circulating angiogenetic and growth factors and may cause tumour progression, whereas lymphocytes control the host immune responses via cytotoxic cell death and by production of cytokines. High neutrophil levels have been identified as an independent predictor of death in patients with advanced non-small cell lung cancer and have also been involved in the promotion of aerogenous metastasis in patients with bronchioloalveolar carcinoma. ${ }^{17,18}$ NLR, was discovered to be a more powerful predictor of death than either component alone. ${ }^{13}$ Studies which show the relationship between preoperative NLR and survival after resection in non-small cell lung cancer are very rare. Sarraf et al. reported that high preoperative NLR is an independent predictor of survival after complete resection for primary lung cancer. They also accepted NLR as a potential biomarker to stratify high risk patients within stage $\mathrm{I} .{ }^{13} \mathrm{Al}-$ though our study did not specifically analyse this relationship according to the TNM stage, it dem-

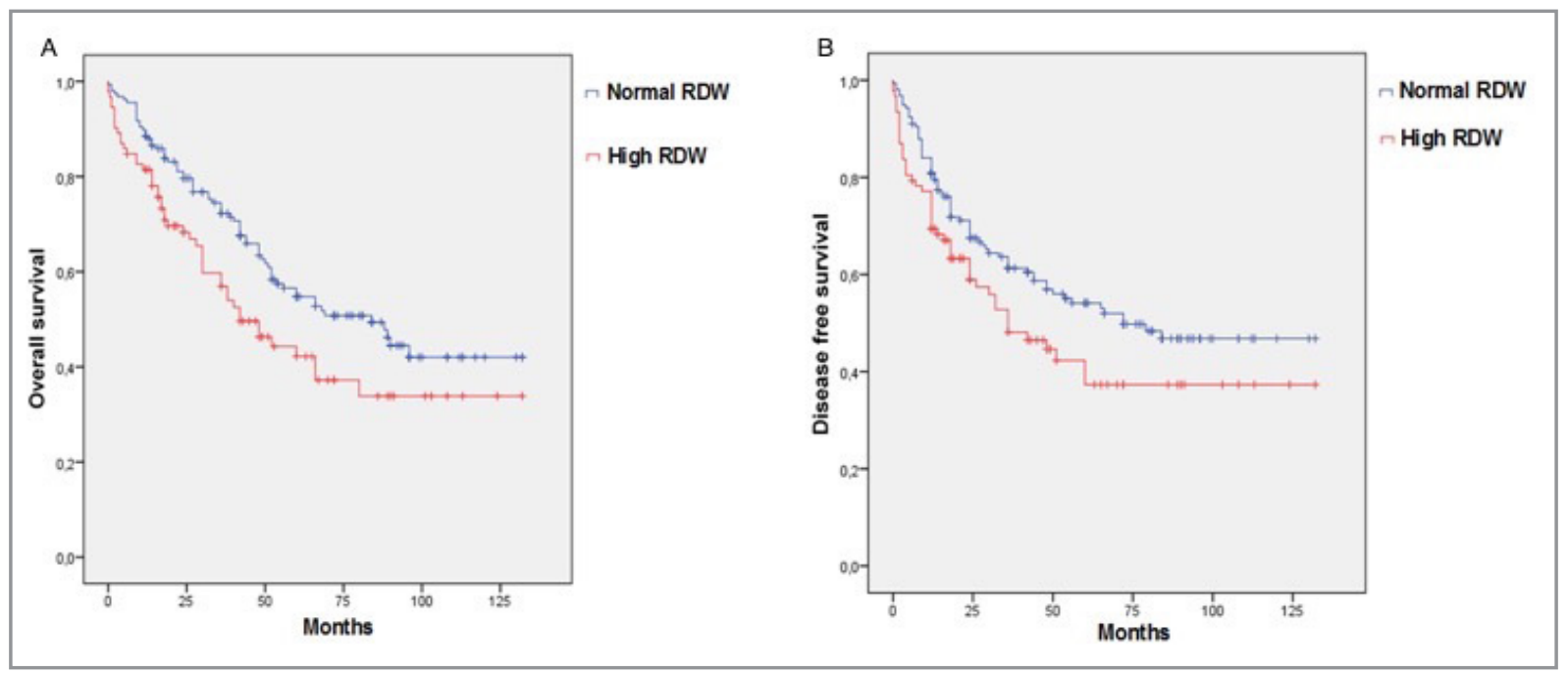

Figure 1 A-B. Correlations between RDW levels and survival rates with Kaplan-Meier Analyses (A: Overall survival, B: Disease free survival) 


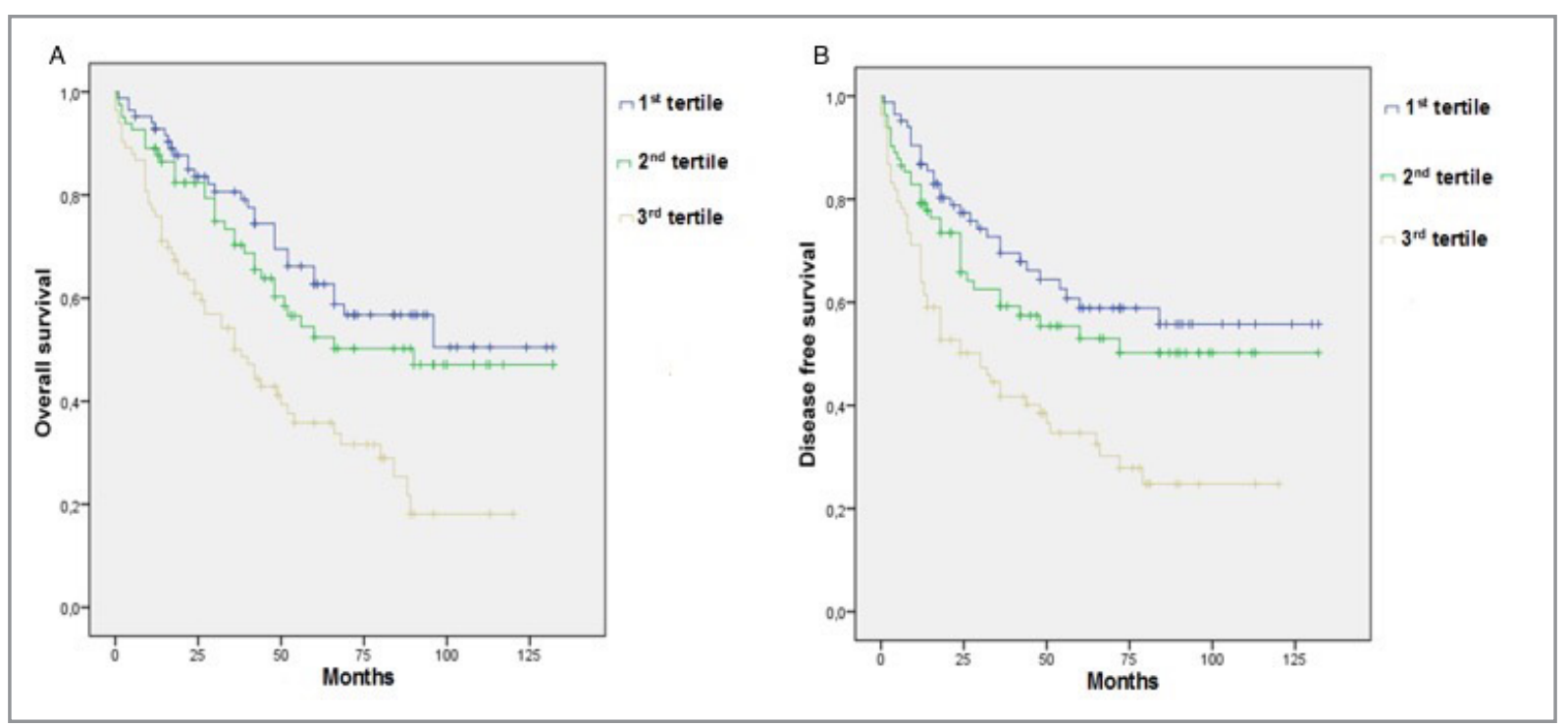

Figure 2 A-B. Correlations between NLR levels and survival rates with Kaplan-Meier Analyses (A: Overall survival, B: Disease free survival)

onstrated that high NLR levels were associated with lower overall and disease free survival rates after complete resection. As given in Table 2, when NLR levels were divided into tertiles we observed significantly poorer overall and disease free survival rates in ascending tertiles. The overall and disease free survival rates in the lower through upper tertiles were respectively $88 \pm 6,80 \pm 6,50 \pm 5$ months for overall and $87 \pm 6,77 \pm 6,47 \pm 5$ months for disease free survival $(p<0.001)$. Likewise, Figure 2 clearly showed that high NLR levels are correlated with poor survival.

There are some limitations in this study. First of all, this is a retrospective study conducted at a single institution. Secondly, since both RDW and NLR levels are affected by many conditions, RDW and NLR levels without other inflammatory indicators such as C-reactive protein, gamma-glutamyl transferase and albumin, may not give exact information about patients' inflammatory status. On the other hand, we could not examine the patients` underlying diseases which could alter the NLR levels. Considering that all operations were scheduled operations we believe the effect of infectious diseases on the RDW and NLR levels to be minimal.

In conclusion, as patients' clinical courses differ and are difficult to predict especially in patients who had undergone pulmonary resection for nonsmall cell lung cancer, the ability to accurately pre- dict sub-sets with poor outcomes is an important consideration and can be used to help select appropriate patients for different therapeutic strategies. RDW and NLR are biomarkers to influence patient selection in this regard. Preoperative measurement of these potential markers are simple, adds no additional cost to routine preoperative workup and can be used for identifying patients with poorer prognosis. However, the exact mechanism of their impact on survival should be sorted out through further researches and clinical trials.

\section{REFERENCES}

1. Douglas SW, Adamson JW. The anemia of chronic disorders: studies of marrow regulation and iron metabolism. Blood 45: 55-65, 1975.

2. Ferrucci L, Guralnik JM, Woodman RC, et al. Proinflammatory state and circulating erythropoietin in persons with and without anemia. Am J Med 118: 1288, 2005.

3. Felker GM, Allen LA, Pocock SJ, et al. Red cell distribution width as a novel prognostic marker in heart failure: data from the CHARM Program and the Duke Databank. J Am Coll Cardiol 50: 40-47, 2007.

4. Balta S, Aydogan M, Kurt O, et al. Red cell distribution width as a novel, simple, inexpensive predictor of mortality in patients with chronic heart failure. Int J Cardiol 168: 3049-3050, 2013.

5. Jo YH, Kim K, Lee JH, et al. Red cell distribution width is a prognostic factor in severe sepsis and septic shock. Am J Emerg Med 31: 545-548, 2013. 
International Journal of Hematology and Oncology

6. Balta S, Arslan Z, Unlu M, Demirkol S. The association between red cell distribution width and non-small-cell lung cancer. Eur J Cardiothorac Surg 45: 954, 2014.

7. Warwick R, Mediratta N, Shackcloth M, et al. Preoperative red cell distribution width in patients undergoing pulmonary resections for non-small-cell lung cancer. Eur J Cardiothorac Surg 45: 108-113, 2014.

8. Chochi $\mathrm{K}$, Ichikura T, Majima $\mathrm{T}$, et al. The increase of CD57+ T cells in the peripheral blood and their impaired immune functions in patients with advanced gastric cancer. Oncol Rep 10: 1443-1448, 2003

9. Hirashima M, Higuchi S, Sakamoto K, Nishiyama T, Okada H. The ratio of neutrophils to lymphocytes and the phenotypes of neutrophils in patients with early gastric cancer. $\mathrm{J}$ Cancer Res Clin Oncol 124: 329-334, 1998.

10. Schmidt H, Bastholt L, Geertsen P, et al. Elevated neutrophil and monocyte counts in peripheral blood are associated with poor survival in patients with metastatic melanoma: a prognostic model. Br J Cancer 93: 273-278, 2005.

11. Walsh SR, Cook EJ, Goulder F, Justin TA, Keeling NJ. Neutrophil-lymphocyte ratio as a prognostic factor in colorectal cancer. J Surg Oncol 91: 181-184, 2005.

12. Fogar P, Sperti C, Basso D, et al. Decreased total lymphocyte counts in pancreatic cancer: an index of adverse outcome. Pancreas 32: 22-28, 2006.

13. Sarraf KM, Belcher E, Raevsky E, et al. Neutrophil/lymphocyte ratio and its association with survival after complete resection in non-small cell lung cancer. J Thorac Cardiovasc Surg 137: 425-428, 2009.

14. Koma Y, Onishi A, Matsuoka H, et al. Increased red blood cell distribution width associates with cancer stage and prognosis in patients with lung cancer. PloS one 11: e80240, 2013.

15. McMillan DC. Systemic inflammation, nutritional status and survival in patients with cancer. Curr Opin Clin Nutr Metab Care 12: 223-226, 2009.
16. Weiss G, Goodnough LT. Anemia of chronic disease. New Eng J Med 352: 1011-1023, 2005.

17. Paesmans M, Sculier JP, Libert $P$, et al. Prognostic factors for survival in advanced non-small-cell lung cancer: univariate and multivariate analyses including recursive partitioning and amalgamation algorithms in 1,052 patients. The European Lung Cancer Working Party. J Clin Oncol 13: 1221-1230, 1995.

18. Wislez M, Antoine M, Rabbe $N$, et al. Neutrophils promote aerogenous spread of lung adenocarcinoma with bronchioloalveolar carcinoma features. Clin Cancer Res 13: 35183527, 2007.

\section{Correspondence}

Dr. Ulaş KUMBASAR

Hacettepe Üniversitesi Tıp Fakültesi

Göğüs Cerrahisi Anabilim Dalı

06100 Sinhiye, Ankara

Tel: (+90-312) 3051774

E-mail: ulaskumbasar@gmail.com 